This situation occurs because points for medical problems contribute little to the points total. Data from six housing authorities in Wales (see table) that use the points system show that the total number of points which can be granted on medical grounds, and therefore the effectiveness of normal medical intervention, varies markedly. ${ }^{1}$ Within these authorities the maximum number of medical points attainable as a percentage of the lowest

Value of medical points in relation to qualifying threshold for rehousing in six housing authorities in Wales*

\begin{tabular}{c|c|c|c}
\hline $\begin{array}{c}\text { Housing } \\
\text { authority }\end{array}$ & $\begin{array}{c}\text { Maximum } \\
\text { medical } \\
\text { points }\end{array}$ & $\begin{array}{c}\text { Qualifying } \\
\text { threshold } \\
\text { for } \\
\text { rehousing } \\
\text { points }\end{array}$ & $\begin{array}{c}\text { Maximum } \\
\text { medical } \\
\text { points } \\
\text { as } \\
\text { qualifying } \\
\text { threshold }\end{array}$ \\
\hline A & 30 & $45-50$ & $60-67$ \\
B & 5 & $35-40$ & $13-14$ \\
C & 15 & $32-36$ & $42-47$ \\
D & 3 & $8-17$ & $18-38$ \\
E & 15 & 28 & 54 \\
F & 20 & $37-50$ & $40-54$
\end{tabular}

*Based on data from Appendix 3 of reference 1

qualifying threshold for rehousing ranges from $13^{\prime \prime}$ " to $60^{\prime \prime}$.. Other methods of housing allocation also exist: of the 39 Welsh authorities studied, ${ }^{1} 29$ used the points system, four used the merit system (all cases reviewed by committee), and six used the date-order system (usually first come, first served). The effectiveness of medical intervention under the latter two systems is difficult to assess.

In individual cases in which medical factors have been influential in rehousing it would appear necessary to ensure, as Dr Muir Gray has done, that new accommodation provides a satisfactory outcome. Unfortunately some studies indicate that conditions in new housing estates do not always improve the respiratory ${ }^{2}$ or mental ${ }^{3}$ health or the general amenities ${ }^{4}$ of those rehoused.

H F THOMas $\mathrm{J}$ W G YARNELL

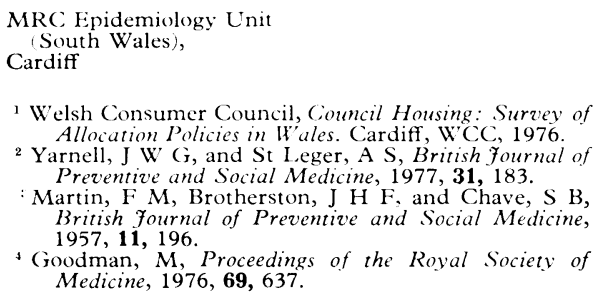

\section{Getting the NHS back on course}

SIR,-The excellent article by Sir Francis Avery Jones (1 July, p 5) mentions the need to refit older buildings and suggests that instead of new general hospitals the next step should be the measurement of existing facilities and equipment. He would have a national Domesday-type survey of general hospitals with a modest number of questions to be answered.

This is a plea for a survey extended to all manner of hospitals that have accommodated 100 patients or more, with emphasis on their basic services. Hospitals do not run withou them and, apart from site acquisition, they absorb a large proportion of the initial capita outlay. It is these essentials-public services, access, power plant, maintenance, transport, resident accommodation for nursing and domestic staffs, catering facilities, laundry, administration-which should be assessed as well as space for doctors. Where there is surplus capacity in good order the upgrading, modification, or increase of accommodation should be economically feasible for some categories of patients.

There could well be a pause in the building of new general hospitals until the NHS is 50 years old if the inquiry revealed reserves. We don't know; and the evidence of surveyors and engineers is required before that of doctors or administrators. Think of the resources of some of the great mental hospitals with rapidly reducing bed demands over the next 20 years.

Let us hope that slow "phasing out" can be avoided, that viable ancillary units of general hospitals are fully exploited, and that "area" boundaries are ignored. Resulting economies might even allow patients trave vouchers for their visitors where distance proved a problem.

HaRLey STEvens

Peppard, Oxon

\section{Thirty years of the NHS}

SIR,-Like Dr Adrian Rogers (1 July, p 59) I face a potential 30 years in the NHS, bu this appears to be the only point which we have in common.

It is true that the NHS is under-financed but its underlying concept of divorcing the delivery of health care from the ability to pay remains a great achievement. I find it difficul to believe that handing its potentially profitable sectors over to private entrepreneurs would improve the service for the population as a whole.

The medical challenges of the next 20 years will be found among the aged, the chronically disabled, and the need to expand preventive medicine. Even in the USA private enterprise has shown itself quite unable to deal with these problems, most of which have been entrusted to the public sector. Despite a vast expenditure the health achievements of th United States, as illustrated, for example, by their infant mortality rate, remain unimpressive. Do we really want to return to the gross maldistribution of health care of pre-NHS days to which Lord Taylor refers (1 July, p 33)?

Most of the deficiencies of the NHS have resulted from the willingness of successive governments to use it as a means of regulating the economy rather than as a system for promoting health. Over the 30 years of it existence the NHS and its finances have rarely been out of the news. Because of this the general public, far from being "deluded" and "blind," is particularly well informed about health matters and is better able to judge the value of its Health Service than many doctors, or even Sir Keith Joseph. After all, it would not be the Sir Keiths of this world or the medical profession who would find themselves second-class citizens under a private medica system.

Finally I would suggest to Dr Rogers that there are $1 \frac{1}{2}$ million unemployed people in this country, some of them health workers, who would be delighted with a "life sentence" of 30 years in any sort of work, whether superannuated or not.

I wish the NHS good health but a rather more prosperous future, free of public spending cuts.

D G SEyMour

Dundee

\section{Out-of-hours use of clinical pathologists}

SIR,-Your anonymous correspondent (15 July, p 207) may, if he becomes a consultant and director of a laboratory, then bless the time that he has spent doing on-call work and benchwork in general. He is a poor pathologist who is not as competent a technician as any of the rest of his staff. If he is not, how can he keep a check on the standard of work being carried out in his laboratory? How can he train and instruct his juniors? (I hope he has put in time doing some of the washing-up as well.) I agree that it seems wrong that he should be compelled to do on-call work at night because the employing authority can't or won't pay their technicians; but it is certainly not wrong that a pathologist in training should gain plenty of experience in emergency work at night. It is not at all the same thing as doing it in the middle of the day.

T H FLEWETT

Regional Virus Laboratory,

East Birmingham Hospital Birmingham

\section{Locum consultants}

SIR,-The Negotiating Subcommittee of the Central Committee for Hospital Medical Services has for some years now been endeavouring to improve the terms and conditions of service of locum consultants.

Whatever their experience and qualifications, those who act as locum consultants are paid at a rate which is equivalent to the mid-point of the consultant salary scale. The service depends largely upon a pool of retired consultants to do this work and this results in a considerable reduction in remuneration for those who were previously at the maximum of the salary scale and, in many cases, also in receipt of a distinction award. The profession in its evidence to the Review Body for the 1978 review asked that, in future, locum consultant remuneration should be related to the maximum of the salary scale. However, the Review Body declined to make any recommendations in its report.

A further point is that when locum consultants undertake to work away from home the cost of hotel accommodation must be borne by the individual and they are therefore invariably considerably out of pocket, and this considerably reduces the incentive for doing the work.

The Department of Health has declined to take any steps to improve the arrangements for locum consultants, as there appears to be no evidence that employing authorities have difficulty in recruiting such locums. The Negotiating Subcommittee is not convinced that this is the true situation and I should be glad to hear from consultants of any difficulties which authorities have experienced in obtaining locums to cover their work in their absence.

D E BolT
Chairman Negairman, 